\title{
SENAM KEBUGARAN \\ DAN PERMAINAN BOLA \\ VOLLY BERSAMA IBU \\ DESA LANGKURA DAN \\ MASYARAKAT DESA \\ LANGKURA
}

Oleh:

SRI WAHYUNI

9173770410199

wahyuni19091999@gmail.com

1. Bentuk kegiatan

- Senam zumba

- Senam umum

2. Lokasi

Lapangan desa langkura

3. Hari/Tanggal dan waktu

Rabu, 16 September 2020

4. Peserta yang dilibatkan

- Ibu desa dan masyarakat

- Mahasiswi KKLP

5. Alasan Melakukan Kegiatan

- Untuk menjaga kesehatan tubuh

6. Tujuan dan Manfaat

Untuk membantu meningkatkan kebugaran jasmani, mengembangkan keterampilan serta menanamkan nilai mental spiritual kepada individu yang melakukannya.

7. Deskripsi Kegiatan

Tujuan kergiatan ini untuk pembentukan kelenturan tubuh yang menjadi arti penting bagi kelangsungan hidup manusia. 